\title{
Characterization of MB Creatine Kinase Isoform Conversion In Vitro and In Vivo in Dogs
}

\author{
Joseph J. Billadello, Hector L. Fontanet, Amold W. Strauss, * and Dana R. Abendschein \\ Departments of Medicine, Biochemistry, ${ }^{*}$ and Pediatrics, ${ }^{*}$ Washington University School of Medicine, St. Louis, Missouri 63110
}

\begin{abstract}
Time-dependent removal of the $\mathrm{COOH}$-terminal lysine residue from each subunit of tissue MM creatine kinase by plasma carboxypeptidase $\mathbf{N}$ produces two additional isoforms that are readily separated, thereby permitting sensitive, early detection of acute myocardial infarction. Only two isoforms of MB creatine kinase have been detected in plasma leading to speculation that the $\mathrm{COOH}$-terminal lysine on the $\mathrm{B}$ subunit is resistant to hydrolysis. To define the biochemical changes resulting in MB creatine kinase isoform conversion, we incubated highly purified MB creatine kinase from canine myocardium with plasma carboxypeptidase N. Quantitative anion-exchange chromatography of incubation mixtures and serial plasma samples from dogs subjected to coronary occlusion revealed a second, more acidic form evolved with time that was separated from the tissue isoform. Cyanogen bromide digestion of the two isoforms followed by amino acid sequencing of $\mathrm{COOH}-$ terminal peptides showed that MB creatine kinase undergoes removal of the $\mathrm{COOH}$-terminal lysine residue from both $\mathrm{M}$ and $B$ subunits. An intermediate form lacking lysine on the $M$ subunit was delineated during incubations by the combined use of anion-exchange chromatography and conventional electrophoretic techniques. Thus, sequential cleavage of lysine from subunits of MB creatine kinase produces an intermediate isoform that has not been detected previously because of difficulties separating it from the tissue and fully converted isoforms.
\end{abstract}

\section{Introduction}

On activation of muscle, phosphocreatine, representing a storage and transport form of energy, is efficiently transphosphorylated by creatine kinase (ATP: creatine $N$-phosphotransferase, EC 2.7.3.2) to yield ATP as the actual source of energy for contraction (1). Creatine kinase occurs intracellularly as three cytoplasmic isoenzymes as well as a mitochondrial form (2). Each cytoplasmic form is a dimer composed of $\mathbf{M}$ and/or $\mathbf{B}$ subunits expressed in a tissue-specific fashion. Thus, the MM homodimer is predominant in skeletal muscle and the BB homodimer is the major species in brain. The MB heterodimer has been found to comprise between $1 \%$ and $22 \%$ of the total creatine kinase activity present in human myocardium (3), but is absent from extracts of normal skeletal muscle or brain (4).

Address reprint requests to Dr. Billadello, Cardiovascular Division, Box 8086, Washington University School of Medicine, 660 South Euclid Avenue, St. Louis, MO 63110.

Received for publication 11 October 1988 and in revised form 16 December 1988.

J. Clin. Invest.

(C) The American Society for Clinical Investigation, Inc.

0021-9738/89/05/1637/07\$2.00

Volume 83, May 1989, 1637-1643
Accordingly, analysis of plasma MB creatine kinase activity has been used extensively for detection of acute myocardial infarction and quantification of the extent of myocardial injury in patients (5).

Wevers et al. (6) were the first to report that plasma from patients with acute myocardial infarction contained three MM and two MB isoenzyme subforms with different isoelectric points (pI) ${ }^{1}$ (hence isoforms) produced by modification of the primary translation product and separable by electrophoresis in agarose gels. We and others have shown that modification of the MM isoenzyme is characterized by successive removal of the $\mathrm{COOH}$-terminal lysine residue from each $\mathrm{M}$ subunit by plasma carboxypeptidase $\mathrm{N}$ (EC 3.4.12.7) (7-10). This results in sequential and unidirectional conversion of the tissue isoform MM-3 (pI = 7.80) to isoforms MM-2 (pI = 7.50) and MM-1 (pI = 7.20). ${ }^{2}$ Analysis of the relative proportions of MM isoforms in plasma permits very early diagnosis of myocardial infarction and of myocardial reperfusion in response to thrombolytic therapy at a time when plasma MB and total creatine kinase activities are still within the normal reference range (11-14).

A potential limitation of analysis of isoforms of MM creatine kinase for detection of myocardial infarction and reperfusion results from expression of the $M$ subunit at high levels in skeletal muscle. Thus, plasma MM creatine kinase activity may increase in conditions other than myocardial infarction. Quantification of individual isoforms of MB creatine kinase could improve specificity for myocardial infarction. However, whereas MM isoform conversion has been well characterized, similar understanding of the nature of $\mathrm{MB}$ isoform conversion has been limited by technical difficulties with purification of the relatively nonabundant MB isoenzyme from myocardium in sufficient quantities for in vitro studies and by the lack of techniques sufficiently sensitive to permit separation and quantitation of isoforms of $\mathrm{MB}$ in plasma samples early after myocardial infarction. We report a detailed analysis of MB creatine kinase isoform conversion by plasma carboxypeptidase $\mathrm{N}$ and procedures for purification of $\mathrm{MB}$ from tissue and for separation and quantitation of isoforms of MB produced in vitro by digestion with carboxypeptidase $\mathrm{N}$ and in plasma samples after myocardial infarction.

\section{Methods}

Purification of isoenzymes of creatine kinase. Mongrel dogs were anesthetized with pentobarbital sodium $(30 \mathrm{mg} / \mathrm{kg}$, intravenously) and the

1. Abbreviations used in this paper: $\mathrm{CNBr}$, cyanogen bromide; FPLC, fast protein liquid chromatography; pI, isoelectric point(s); PTH, phenylthiohydantoin.

2. Nomenclature conforming to the IUPAC-IUB recommendations (1977) was adopted designating the isoform migrating closest to the anode after electrophoresis as MM-1 followed by MM-2 and the tissue form MM-3. Previously we designated the isoforms as MM-C, MM-B, and MM-A, respectively. 
heart of each was perfused before excision with $0.9 \% \mathrm{NaCl}$ to remove blood rich in albumin. Sections of the left ventricle and of the excised cerebral cortex were frozen at $-20^{\circ} \mathrm{C}$. The $\mathrm{MM}$ and $\mathrm{MB}$ isoenzymes were purified from myocardium and the BB isoenzyme purified from brain as described previously (15), except the elution buffer used for anion-exchange chromatography $(50 \mathrm{mM}$ Tris- $\mathrm{HCl})$ was adjusted to pH 7.0 to improve separation of the MB isoenzyme from albumin and the BB isoenzyme from cytoplasmic proteins. MM was purified further by chromatofocusing as described previously (16). The pooled, dialyzed fractions containing BB activity showed a single protein band after electrophoresis on SDS polyacrylamide gels, and hence did not require additional purification. However, because MB contained several protein moieties as assessed by electrophoresis, it was purified further by an affinity chromatography procedure (protocol provided by Yvonne Maynard, Washington University, St. Louis) with the use of a monoclonal antibody specific for the MB isoenzyme (17). The antibody was coupled to activated Sepharose 4B (Pharmacia LKB Biotechnology, Inc., Piscataway, NJ), following the manufacturer's instructions. The conjugate contained $\sim 5 \mathrm{mg}$ protein $/ \mathrm{ml}$ of Sepharose with a binding capacity of $2.0 \mathrm{mg} \mathrm{MB} / \mathrm{ml}$. After anion-exchange chromatography, fractions containing MB activity were pooled and applied to a 5-ml antibody-Sepharose column. The column was washed with $50 \mathrm{mM}$ Tris-HCl, pH 7.3, containing $250 \mathrm{mM} \mathrm{NaCl}, 20$ $\mathrm{mM}$ EDTA, and $10 \mathrm{mM}$ 2-mercaptoethanol. MB was eluted with 100 $\mathrm{mM}$ diethylamine, $\mathrm{pH} 10.5$, containing $10 \mathrm{mM}$ 2-mercaptoethanol. 1 -ml fractions were collected in tubes containing $200 \mu$ l of neutralizing buffer $(50 \mathrm{mM}$ Tris-HCl, $\mathrm{pH} 7.0)$. Fractions with creatine kinase activity were pooled, dialyzed against $50 \mathrm{mM}$ Tris- $\mathrm{HCl}, \mathrm{pH} 7.0$, containing $5 \mathrm{mM}$ 2-mercaptoethanol for $24 \mathrm{~h}$ and concentrated in ultrafiltration cones (CF25, Amicon Corp., Danvers, MA).

Additional purification of MB was performed by anion-exchange FPLC (Pharmacia Fine Chemicals) with a Mono Q HR 5/5 column (Pharmacia Fine Chemicals) equilibrated with $50 \mathrm{mM}$ Tris-HCl, pH 7.0 , containing $5 \mathrm{mM} 2$-mercaptoethanol. $\mathrm{MB}$ was eluted with a linear gradient of $\mathrm{NaCl}(100-240 \mathrm{mM})$ at a flow rate of $0.5 \mathrm{ml} / \mathrm{min}(5 \mathrm{mM}$ $\mathrm{NaCl} / \mathrm{min}$ ). Fractions with creatine kinase activity were pooled and dialyzed against $50 \mathrm{mM}$ Tris- $\mathrm{HCl}, \mathrm{pH} 7.7$, for $24 \mathrm{~h}$.

Digestion with carboxypeptidase $B$. Purified isoenzymes of creatine kinase in $50 \mathrm{mM}$ Tris- $\mathrm{HCl}(\mathrm{pH} \mathrm{7.7)}$ were incubated at room temperature for 30 min with pancreatic carboxypeptidase B (Behring Diagnostics, La Jolla, CA) in a mass ratio of 1:50 of carboxypeptidase to creatine kinase.

Digestion with carboxypeptidase $N$. MB purified from canine myocardium in $50 \mathrm{mM}$ Tris- $\mathrm{HCl}$ (pH 7.7) was incubated with carboxypeptidase $\mathrm{N}$ purified from canine plasma (18) (provided by $\mathrm{Dr}$ Thomas H. Plummer, Wadsworth Laboratories, Albany, NY). The carboxypeptidase activity in the mixture was measured and adjusted to be similar to that present in canine plasma in vivo (400-1,000 U/liter). Incubations were performed until the tissue form of $\mathrm{MB}$ was completely converted or until conversion was $50 \%$ complete as assessed by analysis of isoform profiles (see below). Reactions were stopped by the addition of 2-mercaptomethyl-3-guanidinoethylthiopropanoic acid (10 $\mu \mathrm{M}$ final concentration). $\mathrm{MB}$ isoforms were separated by fast protein liquid chromatography (FPLC) and fractions containing activity were pooled and dialyzed against $20 \mathrm{mM}$ Tris- $\mathrm{HCl}, \mathrm{pH}$ 8.0. Carboxypeptidase $\mathrm{N}$ activity was not evident in fractions containing creatine kinase activity.

Analysis of isoforms of $M B$. Isoforms of MB were separated by anion-exchange FPLC with the use of a 1-ml Mono Q column (HR 5/5, Pharmacia Fine Chemicals) previously equilibrated at room temperature with $50 \mathrm{mM}$ Tris- $\mathrm{HCl}, \mathrm{pH}$ 7.0, containing $5 \mathrm{mM}$ 2-mercaptoethanol. Isoforms were eluted with a linear gradient of $\mathrm{NaCl}$ from 100 to $220 \mathrm{mM}$ at a flow rate of $0.5 \mathrm{ml} / \mathrm{min}(5 \mathrm{mM} \mathrm{NaCl} / \mathrm{min})$ and quantitated by on-line monitoring of enzymatic activity in the column eluent. Substrates for the coupled enzyme assay of creatine kinase yielding NADPH (single-vial reagents, Behring Diagnostics) were added to the column eluent at a flow rate of $320 \mu \mathrm{l} / \mathrm{min}$ with a peristaltic pump (model 2132, Pharmacia, Inc.). After addition of reagents, the stream was incubated at $37^{\circ} \mathrm{C}$ in a $3.0 \mathrm{~m}$ coil of Teflon tubing $(0.8$ $\mathrm{mm} \mathrm{ID)}$ and absorbance was monitored at $340 \mathrm{~nm}\left(37^{\circ} \mathrm{C}\right)$ in a $2-\mathrm{mm}$ flow-through cell coupled to a recording spectrophotometer (model UA-5, Isco, Inc., Lincoln, NE). Absorbance was recorded continuously during elution of the column. The method was validated by use of mixtures of known amounts of each isoform (data not shown).

$P A G E$. Electrophoresis $(20 \mathrm{~mA})$ was performed with vertical slab gels containing $1 \%$ SDS and $12.5 \%$ acrylamide (16).

Agarose gel electrophoresis. Electrophoresis was performed for $5 \mathrm{~h}$ ( $300 \mathrm{~V}$ for $3 \mathrm{~h}, 350 \mathrm{~V}$ for $2 \mathrm{~h}$ ) with horizontal gels consisting of $1 \%$ agarose A (Pharmacia Fine Chemicals) dissolved in buffer containing $56 \mathrm{mM}$ barbital, $31 \mathrm{mM}$ sodium barbital, $90 \mathrm{mM}$ glycine, $45 \mathrm{mM}$ Tris- $\mathrm{HCl}(\mathrm{pH} \mathrm{8.6)}$, and $10 \mathrm{mM}$ dithiothreitol. Between 25 and $30 \mathrm{mIU}$ of creatine kinase activity in a volume of $5 \mu \mathrm{l}$ was applied to sample wells. Gels were cooled with a circulating water bath at $8^{\circ} \mathrm{C}$. Creatine kinase activity was detected by fluorescence after application of an overlay of cellulose acetate strips saturated with creatine kinase-SVR reagent (Behring Diagnostics) and exposure to long-wavelength ultraviolet light.

Determination of enzyme activity and protein. Creatine kinase activity was assayed spectrophotometrically at $37^{\circ} \mathrm{C}$ with a coupled enzyme system (19), creatine kinase-SVR reagent (Behring Diagnostics), and a miniature centrifugal analyzer (Gemeni; Electro-Nucleonics Inc., Fairfield, NJ). MB activity was assayed by a monoclonal antibody method described previously (17). Carboxypeptidase $\mathrm{N}$ activity was assayed spectrophotometrically as described previously (20). Protein was assayed by the method of Lowry et al. (21).

Determination of $p I$. Isoelectric points of $\mathrm{MB}$ isoforms were determined with the PhastSystem and PhastGel (both Pharmacia Fine Chemicals) containing ampholytes in the $\mathrm{pH}$ range of 4.0-6.5. Purified isoforms and standards $(0.5 \mu \mathrm{g})$ with known $\mathrm{pI}$ were prefocused at $2,000 \mathrm{~V}, 2.0 \mathrm{~mA}$ constant power for $5 \mathrm{~min}$, and separated at $2,000 \mathrm{~V}$, $5.0 \mathrm{~mA}$ for $20 \mathrm{~min}$ at $15^{\circ} \mathrm{C}$.

Digestion with cyanogen bromide. Protein $(12 \mathrm{nmol})$ was dissolved in $70 \%$ formic acid containing a 30 -fold molar excess of cyanogen bromide $(\mathrm{CNBr})$ and kept at room temperature overnight in the dark. Samples were dried by lyophilization and resuspended in $25 \%$ trifluoroacetic acid in preparation for HPLC.

HPLC. Peptides were separated by reverse-phase HPLC with a model 5020 system (Varian Associates, Inc., Palo Alto, CA) and a Bondapak C18 column (Waters Associates, Milford, MA). The column was equilibrated with $0.05 \%$ trifluoroacetic acid (vol/vol). The peptide mixture was eluted at room temperature with a flow rate of 1 $\mathrm{ml} / \mathrm{min}$ by use of a linear gradient of acetonitrile $(0.25 \% / \mathrm{min}$ for 120 $\mathrm{min}, 0.50 \% / \mathrm{min}$ for $40 \mathrm{~min}$, and $2.0 \% / \mathrm{min}$ for $25 \mathrm{~min}$ ) containing $0.05 \%$ trifluoroacetic acid.

Amino acid analysis. Peptides were hydrolyzed with $6 \mathrm{~N} \mathrm{HCl}$ in sealed, evacuated glass tubes at $110^{\circ} \mathrm{C}$ for $24 \mathrm{~h}$. Amino acid analyses were performed on a Waters programmable gradient high-pressure liquid chromatograph with postcolumn detection of ortho-phthalaldehyde derivatives and continuous hypochlorite infusion for the quantification of proline (22). The yield of individual amino acid residues is reported relative to that of alanine.

Sequencing procedures. Peptides were sequenced from the $\mathrm{NH}_{2}$ terminus with a model 470A (Applied Biosystems, Inc., Foster City, $\mathrm{CA}$ ) gas-phase protein sequenator and program " $02 \mathrm{~N} \mathrm{Vac"} \mathrm{as} \mathrm{supplied}$ by the manufacturer. Between 0.5 and $2.0 \mathrm{nmol}$ of peptide was subjected to Edman degradation with $95 \%$ repetitive yield. The phenylthiohydantoin (PTH) derivatives recovered after each cycle were identified by quantitative reverse-phase HPLC with a model 1084-B HPLC system (Hewlett-Packard Co., Palo Alto, CA) and a Brownlee C18 (PTH) column (Applied Biosystems).

Preparation of potential intermediate forms of $M B$. To prepare the form of $\mathrm{MB}$ with the $\mathrm{M}$ subunit $\mathrm{COOH}$-terminal lysine cleaved and the B subunit lysine intact (M-lys B+lys), MM (purified from canine myocardium) was digested with carboxypeptidase $B$ and repurified by chromatofocusing to demonstrate complete conversion to $\mathbf{M}$-lys M-lys (MM-1, pI = 7.51). Carboxypeptidase activity was not evident 
in fractions containing the repurified MM-1. Equimolar amounts of MM-1 and BB (purified from canine brain) were mixed. The mixture was made $4 \mathrm{M}$ with guanidine $\mathrm{HCl}$ containing $10.7 \mathrm{mM}$ sodium acetate at $\mathrm{pH} 7.0$, incubated at $30^{\circ} \mathrm{C}$ for $9 \mathrm{~min}$, and dialyzed against 50 $\mathrm{mM}$ Tris- $\mathrm{HCl}$ (pH 7.0) containing $10 \mathrm{mM}$ 2-mercaptoethanol for $72 \mathrm{~h}$ at $4^{\circ} \mathrm{C}$.

To prepare the form of $\mathrm{MB}$ with the $\mathrm{M}$ subunit $\mathrm{COOH}$-terminal lysine intact and the B subunit $\mathrm{COOH}$-terminal lysine cleaved $(\mathrm{M}+$ lys B-lys), BB was digested with carboxypeptidase B and repurified by FPLC with the use of the Mono $Q$ anion-exchange column. Repurified BB eluted from the column as a single peak at $260 \mathrm{mM} \mathrm{NaCl}$ was distinguishable from the tissue form of $\mathrm{BB}$, which eluted at $240 \mathrm{mM}$ $\mathrm{NaCl}$ (see Fig. 6). The fractions containing BB activity did not show carboxypeptidase activity. Equimolar amounts of MM-3 and the converted form of BB were mixed together, denatured, and dialyzed as described above.

Preparation of plasma samples for analysis of $M B$ isoforms. Heparinized blood samples were obtained from normal dogs $(n=6)$, and serially from conscious dogs subjected to coronary artery occlusion ( $n$ = 9) by tightening of a previously implanted coronary ligature as described (14). Samples were centrifuged at $1,600 \mathrm{~g}$ for $10 \mathrm{~min}\left(4^{\circ} \mathrm{C}\right)$, the plasma separated, and EGTA and 2-mercaptoethanol added (10 and $5 \mathrm{mM}$ final concentrations, respectively) to inhibit plasma carboxypeptidase activity and prevent inactivation of creatine kinase activity. Between 3 and $30 \mathrm{ml}$ of plasma was applied to the MB antibody-Sepharose column to separate MB from plasma proteins. After dialysis against $50 \mathrm{mM}$ Tris- $\mathrm{HCl}, \mathrm{pH} 7.0$, containing $5 \mathrm{mM}$ 2-mercaptoethanol, $50-100 \mathrm{mIU}$ of MB activity in a volume of $500 \mu \mathrm{l}$ was applied to the FPLC system described above.

\section{Results}

Purification of $M B$ creatine kinase. MB was purified to homogeneity (Fig. 1, lane $B$ ) with a final specific activity of up to $1,114 \mathrm{U} / \mathrm{mg}$. MB comprised a mean of $6.2 \%$ (range $=4.4-9.7 \%, n=12$ ) of total activity present in canine myocardium.

Qualitative analysis of isoforms of $M B$ and $B B$ creatine kinase by electrophoresis. Complete digestion of MB or BB creatine kinase purified from tissue with carboxypeptidase $B$

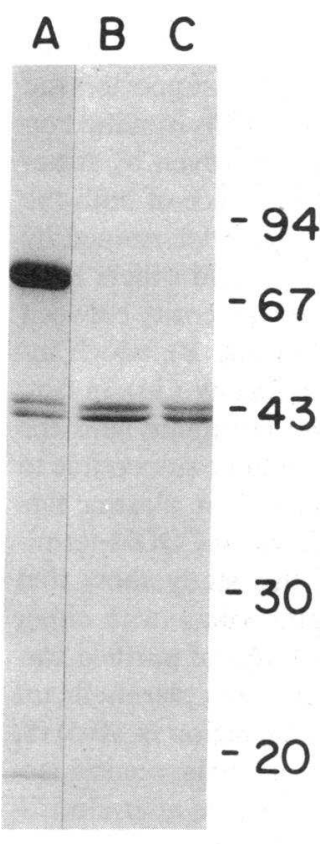

Figure 1. Purification of MB creatine kinase from canine myocardium. MB was purified as described in the experimental procedures. $5 \mu \mathrm{g}$ (lanes $B$ and $C$ ) or $10 \mu \mathrm{g}$ (lane $A$ ) of protein were analyzed by electrophoresis in SDS-polyacrylamide gels. Lane $A$ is the MB isoenzyme fraction after the first anionexchange chromatography step. Lane $B$ shows results after additional purification by MB immunoaffinity chromatography and FPLC on the Mono Q anion-exchange column. Lane $C$ is purified $\mathrm{MB}$ after digestion with carboxypeptidase N. Migration of molecular mass standards in kilodaltons is shown on the right. The $M_{\mathrm{r}}$ of the $\mathrm{B}$ subunit is $41,000 \mathrm{kD}$ and the $M_{\mathrm{r}}$ of the M subunit is $39,000 \mathrm{kD}$. or with carboxypeptidase $\mathrm{N}$ resulted in a second isoform with increased mobility toward the anode relative to the tissue isoform (Fig. 2). However, both the tissue and the converted isoforms of canine MB showed identical mobility after electrophoresis in denaturing SDS-polyacrylamide gels (Fig. 1, lanes $B$ and $C$ ). The $\mathrm{pI}$ of canine MB were 5.25 for the tissue isoform and 5.08 for the isoform resulting after complete digestion with carboxypeptidase.

Quantitative analysis of isoforms of $M B$ creatine kinase in vitro and in vivo. To enable quantification of $\mathrm{MB}$ isoforms, we developed a sensitive, quantitative technique in which FPLC with a Mono $\mathrm{Q}$ anion-exchange column is used. The lower limit of sensitivity of the FPLC system was $5 \mathrm{mIU}$ of creatine kinase activity per isoform peak. The recovery of activity from samples applied to the column was $>85 \%$. MB purified from canine myocardium (Fig. 3) eluted from the column as a single peak of activity at $0.16 \mathrm{M} \mathrm{NaCl}$. Digestion of the myocardial isoform with plasma carboxypeptidase $\mathrm{N}$ in vitro resulted in the appearance of a single second peak of activity that eluted from the column at $0.18 \mathrm{M} \mathrm{NaCl}$ (Fig. 3).

To assess the time course of conversion of $\mathrm{MB}$ in vivo, we measured the relative activities in plasma of the two profiles of MB separated by FPLC at selected time points after myocardial infarction in dogs (Fig. 4). Before coronary occlusion, and in normal unoperated dogs, both peaks of MB activity were present. By $9 \mathrm{~h}$ after coronary artery occlusion, a clear increase in the peak eluting at $0.16 \mathrm{M} \mathrm{NaCl}$ was evident, consistent with release of MB from infarcted myocardium. By $20 \mathrm{~h}$ after coronary artery occlusion, a significant fraction of the tissue form was processed to the converted form, as reflected by an increase in the activity eluting at $0.18 \mathrm{M} \mathrm{NaCl}$.

Isolation and characterization of peptides unique to $M B$ creatine kinase isoforms. To determine the biochemical changes that characterize conversion of $\mathrm{MB}$ creatine kinase isoforms, we prepared $\mathrm{CNBr}$ digests of the tissue and fully converted isoforms and fractionated the digests by HPLC (Fig. 5). Peptide maps of the tissue and converted isoforms were identical except for two peptide peaks. Both peptides present in the map of the tissue isoform (Fig. $5 \mathrm{~B}, \mathrm{~B}+$ lys, $\mathrm{M}+$ lys) were replaced by more hydrophobic peptides in the map of the converted isoform (Fig. $5 \mathrm{~A}$, B-lys, M-lys). The two peptides

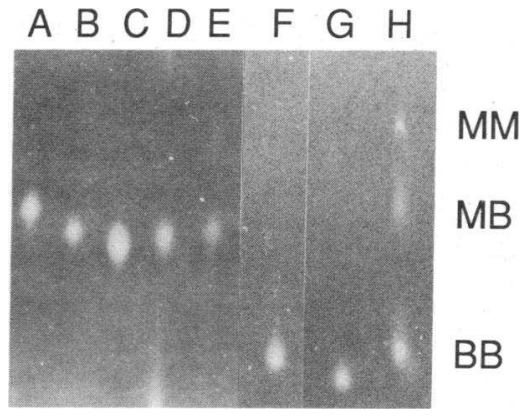

Figure 2. Analysis of isoforms of MB (lanes $A-E$ ) and $\mathrm{BB}$ (lanes $F$ and $G$ ) creatine kinase by electrophoresis in agarose gels. Lane $A$ is the MB isoform purified from canine myocardium. Lane $B$ is the MB activity eluting from the anion-exchange column at 0.16 $\mathrm{M} \mathrm{NaCl}$ after $50 \%$ digestion of MB with carboxypeptidase N, as assessed by FPLC. Lane $C$ is the MB isoform resulting from complete digestion with carboxypeptidase $\mathrm{N}$. Lanes $D$ and $E$ are the $\mathrm{M}-$ lys $\mathrm{B}+$ lys and $\mathrm{M}+$ lys $\mathrm{B}-\mathrm{lys}$ intermediates prepared by hybridization in vitro. Lane $F$ is BB purified from canine brain. Lane $G$ is BB after digestion with carboxypeptidase B. Migration of a mixture of tissue MM, MB, and BB is shown in lane $H$. The origin is at the top, the anode at the bottom. 


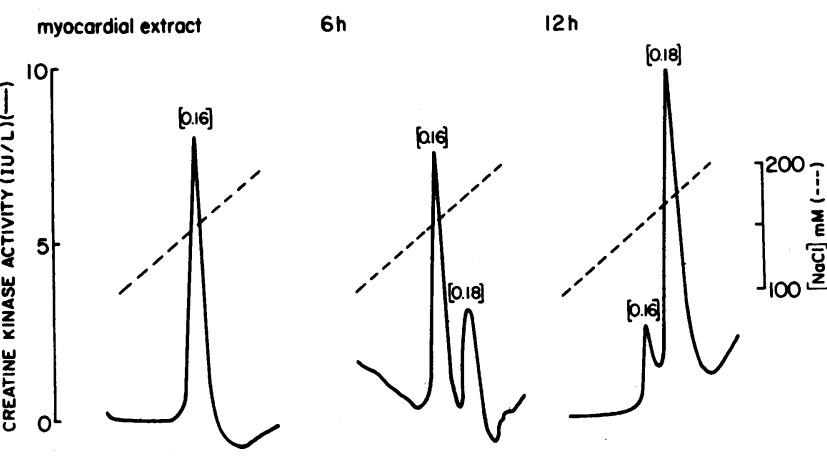

Figure 3. Conversion of isoforms of canine MB creatine kinase in vitro. MB purified from myocardium was digested with carboxypeptidase $\mathrm{N}$ as described in Methods. Aliquots taken at time $0,6 \mathrm{~h}$, and $12 \mathrm{~h}$ were analyzed by FPLC with use of a Mono- $\mathrm{Q}$ anion-exchange column eluted with a linear gradient of $\mathrm{NaCl}$ (right ordinate). The tissue and converted isoforms of $\mathrm{MB}$ elute at $0.16 \mathrm{M} \mathrm{NaCl}$ and 0.18 $\mathrm{M} \mathrm{NaCl}$, respectively.

from the tissue isoform ( $M+$ lys and $\mathrm{B}+$ lys) were subjected to automated Edman degradation (Tables I and II). Comparison of the amino acid sequences of these peptides with the sequences predicted from cDNA clones of canine $M$ and $B$ demonstrated that the sequence of peptide $\mathrm{M}+$ lys corresponds to residues 377 to 381 of the $M$ subunit and the sequence of peptide $\mathrm{B}+$ lys corresponds to residues 364 to 381 of the $B$ subunit, identical to the predicted $\mathrm{COOH}$-terminal $\mathrm{CNBr}$ peptides of $M$ and $B(23,24)$. Analysis of the two peptides unique to the converted isoform ( $\mathrm{M}$-lys and $\mathrm{B}-\mathrm{lys})$ indicated the sequences correspond to residues $377-380$ of $M$ and 364-380 of B creatine kinase, respectively; the predicted $\mathrm{COOH}$-terminal $\mathrm{CNBr}$ peptides of the $\mathrm{M}$ and $\mathrm{B}$ subunits lacking the $\mathrm{COOH}$-terminal lysine residues. These results were confirmed by quantitative amino acid analyses (Table III). Thus, modification of MB creatine kinase by carboxypeptidase $\mathrm{N}$ results from specific cleavage of the $\mathrm{COOH}$-terminal lysine residues from both the $M$ and $B$ subunits.

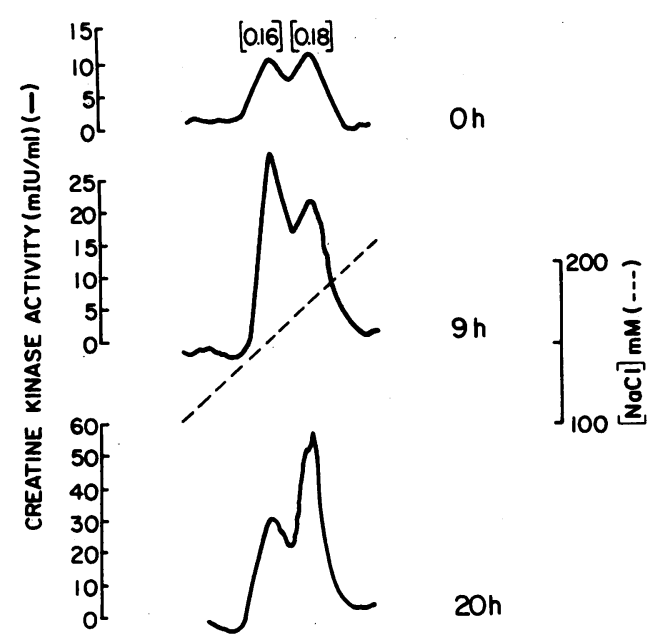

Figure 4. Time course of plasma conversion of MB isoforms after persistent coronary occlusion in a conscious dog. Isoforms were characterized by FPLC as described in Fig. 3.
Characterization of potential isoforms of $M B$ lacking one COOH-terminal lysine residue. Two possible intermediate forms of $\mathrm{MB}$ resulting from cleavage of the $\mathrm{COOH}$-terminal lysine residue from either the $M$ subunit (designated $\mathbf{M}$-lys B+lys) or the B subunit (M+lys B-lys) were prepared by hybridization. When analyzed by FPLC, intermediate forms were resolved from each other (Fig. 6). However, the M-lys $B+$ lys form eluted from the FPLC column at $0.16 \mathrm{M} \mathrm{NaCl}$, co-eluting with the tissue isoform. The $\mathrm{M}+$ lys $\mathrm{B}-\mathrm{lys}$ form eluted from the FPLC column at $0.18 \mathrm{M} \mathrm{NaCl}$, co-eluting with the converted isoform. Thus, cleavage of the $\mathrm{COOH}$-terminal lysine residue from the $B$ subunit but not the $M$ subunit changes the elution profile of the isoenzyme from the anionexchange column.

In contrast to the results obtained by FPLC, agarose electrophoresis separated both intermediate forms from the more cathodal tissue isoform (Fig. 2). However, electrophoresis did not appear to resolve the intermediates from each other or clearly separate them from the more anodal converted isoform (Fig. 2). Thus, cleavage of the $\mathrm{COOH}$-terminal lysine residue from either the $M$ or $B$ subunit results in a change in migration of $\mathrm{MB}$ after electrophoresis in agarose gels.

To determine whether intermediate forms are induced during digestion with carboxypeptidase, we partially digested the tissue isoform with carboxypeptidase $\mathrm{N}$ until an aliquot of the digest showed a 50:50 mixture of the two activity profiles by FPLC. Analysis by electrophoresis of the activity peak eluting from the anion-exchange column at $0.16 \mathrm{M} \mathrm{NaCl}$ showed a single band with migration more anodal than the tissue isoform (Fig. 2); and similar to the migration of both intermediate forms ( $\mathrm{M}+$ lys $\mathrm{B}$-lys and $\mathrm{M}$-lys $\mathrm{B}+$ lys). However, because cleavage of the $\mathrm{COOH}$-terminal lysine from the $\mathrm{B}$ subunit was shown to result in elution from the anion-exchange column at $0.18 \mathrm{M} \mathrm{NaCl}$ (Fig. 6), the intermediate form identified in the activity peak at $0.16 \mathrm{M} \mathrm{NaCl}$ is probably $\mathrm{M}$-lys B+lys.

\section{Discussion}

Based on delineation of two subforms of MB creatine kinase by agarose electrophoresis after hybridization of MM subforms isolated from plasma and BB purified from brain, Wevers et al. (25) concluded and others have supported the hypothesis (26) that only the M subunit of MB is modified by plasma factors. However, this has not been proven by structural analysis. Recently, the amino acid sequence of both the $M$ and $B$ subunits of creatine kinase has been determined by cDNA cloning in a number of species. We and others have shown an extraordinary degree of amino acid identity between the $M$ and $B$ subunits ( $81 \%$ for canine $M$ and $B)$, which includes the $\mathrm{COOH}$-terminal region of the molecule (24). In fact, all $M$ and $B$ subunits sequenced to date terminate with the same sequence, Pro-Ala-Gln-Lys, and should be susceptible to digestion by pancreatic carboxypeptidase B or plasma carboxypeptidase $\mathrm{N}$, which favors substrates with a $\mathrm{COOH}$-terminal lysine residue (27). The results of this study show that complete digestion of $\mathrm{MB}$ and $\mathrm{BB}$ creatine kinase with either carboxypeptidase B or with physiologic levels of purified carboxypeptidase $\mathrm{N}$ (recently shown to be the only plasma factor responsible for creatine kinase isoform conversion in vivo) (8, 10) leads to the apparent production of a single, second isoform with increased mobility toward the anode after electro- 


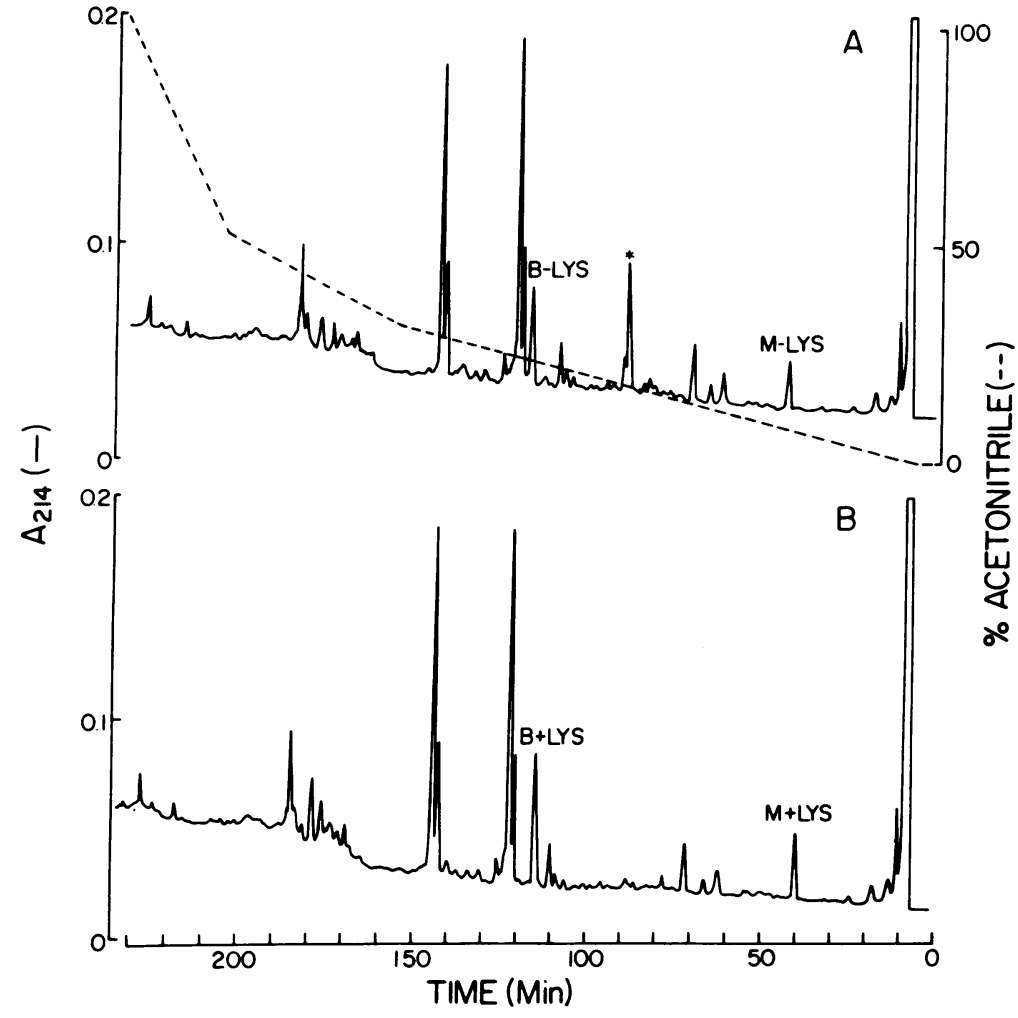

Figure 5. Comparative $\mathrm{CNBr}$ maps of isoforms of canine MB creatine kinase. Complete digestion of myocardial MB $(700 \mu \mathrm{g})$ with carboxypeptidase $\mathrm{N}(A)$ or incubation in buffer ( $50 \mathrm{mM}$ Tris- $\mathrm{HCl}, \mathrm{pH} 7.0$ ) without carboxypeptidase $\mathrm{N}(B)$ was followed by digestion with $\mathrm{CNBr}$ and fractionation by reverse-phase HPLC with use of a linear gradient of acetonitrile (right ordinate). Absorbance peaks containing peptides corresponding to the $\mathrm{COOH}$-terminal $\mathrm{CNBr}$ peptides of the $\mathrm{M}(\mathrm{M}+\mathrm{lys}$, $\mathrm{M}-\mathrm{lys}$ ) and $\mathrm{B}$ (B+lys, B-lys) subunit are identified. The asterisk (*) identifies a peptide with a sequence (PQAPKGQVPNSG) not present in the $M$ or $B$ subunit and presumed to represent a $\mathrm{CNBr}$ peptide derived from carboxypeptidase $\mathrm{N}$. phoresis in agarose gels (Fig. 2), but no change in molecular weight as determined by electrophoresis in denaturing SDSpolyacrylamide gels (Fig. 1). Nevertheless, comparison of peptide maps obtained by fractionation of $\mathrm{CNBr}$ digests of the tissue and converted isoforms of $\mathrm{MB}$ and amino acid analysis of peptides unique to each showed that the COOH-terminal lysine residues were removed from both the $M$ and $B$ subunits of the converted isoform (Fig. 5, Tables I-III). Removal of $\mathrm{COOH}$-terminal lysine residues was the only modification that characterized MB isoform conversion. Because both the $\mathbf{M}$ and $B$ subunits were susceptible to digestion by carboxypeptidases, we hypothesized that MB creatine kinase undergoes se-

Table I. Automated Sequence Analysis of M Subunit COOH-Terminal Peptide

\begin{tabular}{ccrr}
\hline & & \multicolumn{2}{c}{ Yield of PTH amino acid } \\
\cline { 3 - 4 } Cycle number & Assigned amino acid & M + lys & M - lys \\
\hline & & \multicolumn{3}{c}{ pmol } \\
1 & Ile & 1960 & 1080 \\
2 & Pro & 3630 & 1760 \\
3 & Ala & 4140 & 1740 \\
4 & Gln & 2780 & 130 \\
5 & Lys & 40 & 0
\end{tabular}

Corresponding peptides isolated from $\mathrm{CNBr}$ digests of the tissue form of MB (Fig. $5 \mathrm{~B}, \mathrm{M}+$ lys) and the converted form (Fig. $5 \mathrm{~A}, \mathrm{M}$ - lys) were subjected to automated Edman degradation (1.5-2.0 nmol, 10 cycles repeated once).
Table II. Automated Sequence Analysis of B Subunit COOH-Terminal Peptide

\begin{tabular}{cccc}
\hline & & \multicolumn{2}{c}{ Yield of PTH amino acid } \\
\cline { 3 - 4 } Cycle number & Assigned amino acid & B + lys & B - lys \\
\hline & & \multicolumn{2}{c}{ pmol } \\
1 & Glu & 1250 & 228 \\
2 & Gln & 1220 & 183 \\
3 & Arg & $-{ }^{*}$ & $-{ }^{*}$ \\
4 & Leu & 1080 & 174 \\
5 & Glu & 710 & 161 \\
6 & Gln & 750 & 165 \\
7 & Gly & 480 & 161 \\
8 & Gln & 520 & 138 \\
9 & Ala & 400 & 138 \\
10 & Ile & 300 & 103 \\
11 & Asp & 230 & 103 \\
12 & Asp & 280 & 121 \\
13 & Leu & 160 & 76 \\
14 & Val & 230 & 54 \\
15 & Pro & 130 & 71 \\
16 & Ala & 150 & 85 \\
17 & Gln & 96 & 45 \\
18 & Lys & 44 & 0 \\
& & & \\
& & &
\end{tabular}

Corresponding peptides isolated from $\mathrm{CNBr}$ digests of the tissue form of MB (Fig. $5 B$, B + lys) and the converted form (Fig. $5 A$, B - lys) were subjected to automated Edman degradation (0.5-1.5 nmol, 25 cycles repeated once).

* Qualitative identification only. 
Table III. Amino Acid Analysis of COOH-Terminal Peptides

\begin{tabular}{|c|c|c|c|c|}
\hline Amino acid & $M+$ lys & M - lys & $B+$ lys & B - lys \\
\hline & \multicolumn{4}{|c|}{ residues $/ \mathrm{mol}^{*}$} \\
\hline Aspartic acid & & & $1.6(2)^{\ddagger}$ & $2.50(2)$ \\
\hline \multicolumn{5}{|l|}{ Threonine } \\
\hline \multicolumn{5}{|l|}{ Serine } \\
\hline Glutamic acid & $1.3(1)$ & $1.3(1)$ & $6.2(6)$ & $7.0(6)$ \\
\hline Proline & $1.0(1)$ & $0.9(1)$ & $0.8(1)$ & $1.3(1)$ \\
\hline Glycine & & & $1.4(1)$ & $1.7(1)$ \\
\hline Alanine & $1.0(1)$ & $1.0(1)$ & $2.0(2)$ & $2.0(2)$ \\
\hline Valine & & & $0.6(1)$ & $0.8(1)$ \\
\hline \multicolumn{5}{|l|}{ Methionine } \\
\hline Isoleucine & $0.9(1)$ & $1.0(1)$ & $0.4(1)$ & $0.9(1)$ \\
\hline Leucine & & & $1.6(2)$ & $2.3(2)$ \\
\hline \multicolumn{5}{|l|}{ Tyrosine } \\
\hline \multicolumn{5}{|l|}{ Phenylalanine } \\
\hline Lysine & $0.8(1)$ & $0.2(0)$ & $1.2(1)$ & $0.3(0)$ \\
\hline \multicolumn{5}{|l|}{ Histidine } \\
\hline Arginine & & & $1.0(1)$ & $1.3(1)$ \\
\hline Total & (5) & (4) & (18) & (17) \\
\hline
\end{tabular}

The $\mathrm{CNBr}$ peptides contained in the peaks identified in Fig. 5 were subjected to amino acid analysis as described in experimental procedures.

* Composition data have been converted to express the number of individual amino acids normalized to alanine.

\# Values in parentheses indicate the predicted number of residues deduced from the cDNA sequence, or in the case of $(0)$ the amino acid sequence of the peptide.

quential cleavage of $\mathrm{COOH}$-terminal lysine residues in plasma analogous to that shown previously for MM creatine kinase (7) which involved induction of an intermediate isoform with the $\mathrm{COOH}$-terminal lysine residue removed from one subunit. To evaluate this possibility, we prepared by hybridization both potential intermediate forms lacking lysine on either the $M$ subunit (M-lys B+lys) or the B subunit (M+lys B-lys). Intermediate forms exhibited mobilities after electrophoresis more anodal than the tissue isoform (Fig. 2), although separation

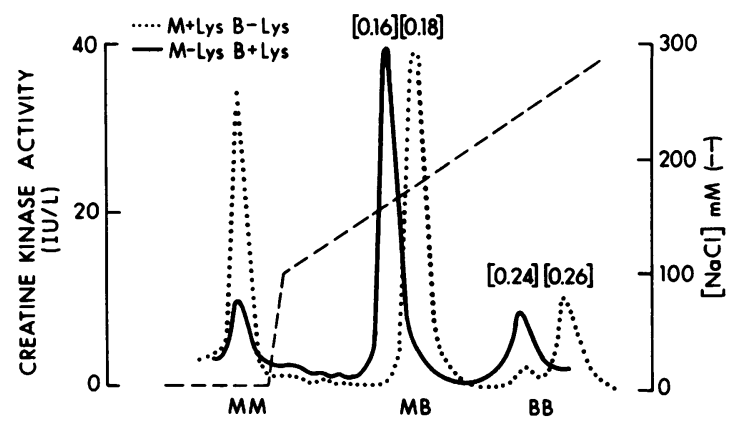

Figure 6. Separation of potential intermediate forms of MB produced by hybridization in vitro. Hybridization mixtures were separated by FPLC as described in Fig. 3. MM elutes in the void volume of the FPLC column without resolving isoforms. Intermediate forms of MB, M-lys B+lys and M+lys B-lys, elute at 0.16 and $0.18 \mathrm{M}$ $\mathrm{NaCl}$, respectively. The tissue form of $\mathrm{BB}$ elutes at $0.24 \mathrm{M} \mathrm{NaCl}$ and the converted form of BB (B-lys B-lys) elutes at $0.26 \mathrm{M} \mathrm{NaCl}$. from the fully converted isoform did not appear complete and there was no detectable difference in mobility between the intermediates. Conversely, analysis by high-resolution anionexchange chromatography separated the intermediates from each other but not from the tissue isoform, which co-eluted at $0.16 \mathrm{M} \mathrm{NaCl}$ with the $\mathrm{M}$-lys $\mathrm{B}+$ lys form, or from the fully converted isoform, which co-eluted at $0.18 \mathrm{M} \mathrm{NaCl}$ with the M+lys B-lys form (Fig. 6). Interestingly, elution at $0.18 \mathrm{M}$ $\mathrm{NaCl}$ appeared dependent on removal of the $\mathrm{COOH}$-terminal lysine residue from the B subunit. Based on this finding, we attempted to verify induction of the $\mathbf{M}$-lys $\mathbf{B}+$ lys intermediate during incubations of tissue isoform with plasma carboxypeptidase $\mathrm{N}$. Incubation was continued until the activity was approximately equivalent in the $0.16 \mathrm{M}$ and $0.18 \mathrm{M} \mathrm{NaCl}$ profiles separated by the anion-exchange column. Electrophoresis of the activity eluting at $0.16 \mathrm{M} \mathrm{NaCl}$, and therefore containing an intact lysine on the B subunit, exhibited migration more anodal than the tissue isoform, consistent with induction of the $\mathbf{M}$-lys $\mathrm{B}+$ lys intermediate (Fig. 2). Thus, one intermediate form of $\mathrm{MB}$ (M-lys $\mathrm{B}+$ lys) was demonstrated in vitro during modification by plasma carboxypeptidase. However, the intermediate could go virtually undetected by agarose electrophoresis because of its migration in close proximity and possible confusion with the fully converted isoform. The second potential intermediate (M+lys B-lys) probably does not exist because electrophoresis of activity eluting from the anion-exchange column at $0.18 \mathrm{M} \mathrm{NaCl}$ (indicating cleavage of lysine from the B subunit) after $50 \%$ conversion exhibited migration closest to the anode, indistinguishable from the fully converted isoform (Fig. 2), consistent with cleavage of lysine from the $\mathrm{M}$ subunit. Accordingly, the results indicate that $\mathrm{MB}$ creatine kinase subjected to digestion by plasma carboxypeptidase $\mathrm{N}$ in vitro undergoes sequential cleavage of the $\mathrm{COOH}$ terminal lysine residues on the $M$ and then the $B$ subunit leading to induction of an $\mathrm{M}$-lys $\mathrm{B}+$ lys intermediate isoform.

Modification of the B subunit in vivo after coronary artery occlusion in dogs was demonstrated by a time-dependent increase in the proportion of activity eluting from the anion-exchange column at $0.18 \mathrm{M} \mathrm{NaCl}$ (Fig. 4). Under baseline conditions, approximately one-half of the $\mathrm{MB}$ activity eluted at $0.16 \mathrm{M} \mathrm{NaCl}$ (Fig. 4). Because baseline activity of $\mathrm{MB}$ creatine kinase was too low to evaluate by electrophoresis, it is not clear whether the activity eluted from the anion-exchange column at $0.16 \mathrm{M} \mathrm{NaCl}$ comprises tissue isoform, $\mathrm{M}$-lys $\mathrm{B}+$ lys intermediate or both. However, judging from the high proportion of fully converted MB isoform in normal canine plasma (Fig. 4) and the relatively low baseline proportion of the MM isoform from tissue documented previously $(11,13)$, it seems likely that the profile at $0.16 \mathrm{M} \mathrm{NaCl}$ represents primarily the M-lys B+lys intermediate.

Previous studies of MB isoenzyme modifications have been hampered by the inability to obtain highly purified MB from myocardium (25), by the insensitivity of assays for MB isoforms (28) and because MB is unstable at its isoelectric point leading to denaturation with loss of activity. MB purified by our procedure was homogeneous as assessed by SDS-polyacrylamide gel electrophoresis and had a specific activity among the highest reported to date. The high-resolution anion-exchange chromatography method developed has facilitated purification of sufficient quantities of individual isoforms of MB to determine the nature of their modification by carboxypeptidase $\mathrm{N}$. Its high sensitivity has enabled character- 
ization of the time course of conversion of $\mathrm{MB}$ isoforms in dogs after myocardial infarction and provided insight to the isoform composition in plasma under physiologic conditions. Although the method does not separate the tissue isoform from the $\mathbf{M}-$ lys $\mathbf{B}+$ lys intermediate, it distinguishes these isoforms from the fully converted isoform and therefore will be useful to monitor MB isoform conversion in vivo. Implementation of methods for separation of all isoforms of MB creatine kinase will facilitate application of isoform analysis for early and specific detection of myocardial infarction and reperfusion.

\section{Acknowledgments}

We thank Ann M. Grace, Cindy L. McMullan, and Gina Vago for technical assistance, Kelly Hall for secretarial assistance, Dr. Jack $\mathbf{H}$. Ladenson and Yvonne Maynard for providing the monoclonal antibody and protocol for immunoaffinity chromatography, and the Protein Chemistry Facility at Washington University for peptide sequencing and amino acid analyses.

This work was supported in part by National Institutes of Health grants HL-38868 and HL-17646 SCOR in Ischemic Heart Disease. Dr. Billadello is the recipient of a Syntex Scholars Award.

\section{References}

1. Watts, D. C. 1973. Creatine kinase (adenosine 5 ' triphosphatecreatine phosphotransferase). In The Enzymes. P. D. Boyer, editor, Academic Press, Inc. New York. 383-455.

2. Grace, A. M., M. B. Perryman, and R. Roberts. 1983. Purification and characterization of human mitochondrial creatine kinase. A single enzyme form. J. Biol. Chem. 258:15346-15354.

3. Ingwall, J. S., M. F. Kramer, M. A. Fifer, B. H. Lorell, R. Shemin, W. Grossman, and P. D. Allen. 1985. The creatine kinase system in normal and diseased human myocardium. N. Engl. J. Med. 313:1050-1054.

4. Roberts, R., K. S. Gowda, P. A. Ludbrook, and B. E. Sobel. 1975. Specificity of elevated serum MB creatine phosphokinase activity in the diagnosis of acute myocardial infarction. Am. J. Cardiol. $36: 433-437$

5. Hackel, D. B., K. A. Reimer, R. E. Ideker, and the MILIS study group. 1984. Comparison of enzymatic and anatomic estimates of myocardial infarct size in man. Circulation. 70:824-835.

6. Wevers, R. A., H. P. Olthuis, J. C. C. Van Niel, M. G. M. Van Wilgenburg, and J. B. J. Soons. 1977. A study on the dimeric structure of creatine kinase (EC2.7.3.2). Clin. Chem. Acta. 75:377-385.

7. Billadello, J. J., D. G. Roman, A. M. Grace, B. E. Sobel, and A. W. Strauss. 1985. The nature of post-translational formation of MM creatine kinase isoforms. J. Biol. Chem. 260:14988-14992.

8. Abendschein, D. R., H. Serota, T. H. Plummer, Jr., K. Amiraian, A. W. Strauss, B. E. Sobel, and A. S. Jaffe. 1987. Conversion of MM creatine kinase isoforms in human plasma by carboxypeptidase N. J. Lab. Clin. Med. 110:798-806.

9. Perryman, M. B., J. D. Knell, and R. Roberts. 1984. Carboxypeptidase-catalyzed hydrolysis of C-terminal lysine: mechanism for in vivo production of multiple forms of creatine kinase in plasma. Clin. Chem. 30:662-664.

10. Michelutti, L., H. Falter, S. Certossi, B. Marcotte, and A. Mazzuchin. 1987. Isolation and purification of creatine kinase conversion factor from human serum and its identification as carboxypeptidase $\mathrm{N}$. Clin. Biochem. 20:21-29.

11. Jaffe, A. S., H. Serota, A. Grace, and B. E. Sobel. 1986. Diagnostic changes in plasma creatine kinase isoforms early after the onset of acute myocardial infarction. Circulation. 74:105-109.

12. Puleo, P. R., M. B. Perryman, M. A. Bressner, R. Rokey, C. M. Pratt, and R. Roberts. 1987. Creatine kinase isoform analysis in the detection and assessment of thrombolysis in man. Circulation. 75:1162-1169.

13. Hashimoto, H., D. R. Abendschein, A. W. Strauss, and B. E. Sobel. 1985. Early detection of myocardial infarction in conscious dogs by analysis of plasma MM creatine kinase isoforms. Circulation. 71:363-369.

14. Devries, S. R., B. E. Sobel, and D. R. Abendschein. 1986. Early detection of myocardial reperfusion by assay of plasma MM-creatine kinase isoforms in dogs. Circulation. 74:567-572.

15. Grace, A., and R. Roberts. 1982. Improved procedures for purification of human and canine creatine kinase isoenzymes. Clin. Chim. Acta. 123:59-71.

16. Hashimoto, H., A. M. Grace, J. J. Billadello, R. W. Gross, A. W. Strauss, and B. E. Sobel. 1984. Nondenaturing quantification of subforms of canine MM creatine kinase isoenzymes (isoforms) and their interconversion. J. Lab. Clin. Med. 103:470-484.

17. Vaidya, H. C., Y. Maynard, D. N. Dietzler, and J. H. Ladenson. 1986. Direct measurement of creatine kinase-MB activity in serum after extraction with a monoclonal antibody specific to the MB isoenzyme. Clin. Chem. 32:657-663.

18. Plummer, T. H., and M. Y. Hurwitz. 1978. Human plasma carboxypeptidase N. J. Biol. Chem. 253:3907-3912.

19. Rosalki, S. D. 1967. An improved procedure for serum creatine phosphokinase determination. J. Lab. Clin. Med. 69:696-705.

20. Plummer, T. H., and M. T. Kimmel. 1980. An improved spectrophotometric assay for human plasma carboxypeptidase N. Anal. Biochem. 108:348-353.

21. Lowry, O. H., N. J. Rosebrough, A. C. Farr, and R. J. Randall. 1951. Protein measurement with the Folin phenol reagent. J. Biol. Chem. 193:265-275.

22. Dixit, U. M., G. A. Grant, S. A. Santoro, and W. A. Frazier. 1984. Isolation and characterization of a heparin-binding domain from the amino terminus of platelet thrombospondin. J. Biol. Chem. 259:10100-10105.

23. Roman, D., J. Billadello, J. Gordon, A. Grace, B. Sobel, and A. Strauss. 1985. Complete nucleotide sequence of dog heart creatine kinase mRNA: Conservation of amino acid sequence within and among species. Proc. Natl. Acad. Sci. USA. 82:8394-8398.

24. Billadello, J. J., D. P. Kelly, D. G. Roman, and A. W. Strauss. 1986. The complete nucleotide sequence of canine brain B creatine kinase mRNA: homology in the coding and $3^{\prime}$ noncoding regions among species. Biochem. Biophys. Res. Commun. 138:392-398.

25. Wevers, R. A., R. J. Wolters, and J. B. J. Soons. 1977. Isoelectric focusing and hybridization experiments on creatine kinase (EC 2.7.3.2). Clin. Chim. Acta. 78:271-276.

26. Roberts, R. 1987. Reperfusion and the plasma isoforms of creatine kinase isoenzymes: a clinical perspective. J. Am. Coll. Cardiol. 9:464-466.

27. Oshima, G., J. Kato, and E. C. Erdos. 1975. Plasma carboxypeptidase N, subunits and characteristics. Arch. Biochem. Biophys. 170:132-138

28. Panteghini, M., C. Cuccia, A. Malchiodi, M. Calarco, and N. Pagnoni. 1986. Isoforms of creatine kinase $M M$ and $M B$ in acute myocardial infarction: a clinical evaluation. Clin. Chim. Acta. 155:110. 